\title{
PERLINDUNGAN DATA PRIBADI SEBAGAI BAGIAN DARI HAK ASASI MANUSIA ATAS PERLINDUNGAN DIRI PRIBADI
}

\author{
Upik Mutiara1, Romi Maulana ${ }^{1}$ \\ 1Universitas Muhammadiyah Tangerang, \\ Magister Hukum \\ Jalan Perintis Kemerdekaan I Babakan No.33, RT.007/RW.003, Cikokol, Kec. Tangerang, Kota Tangerang, Banten \\ 15118 \\ *upikmutiara.umt@gmail.com
}

\begin{abstract}
Protection of personal data as closely related to the protection of personal and private rights. Indonesia does not yet have legislation that specifically regulates the protection of personal data. then the problem that the author raises is: the comparison of the right to personal protection as part of human rights in Indonesia with the constitution in other countries and the concept of comparing the protection of personal data as a manifestation of the human rights of personal protection in Indonesia and other countries. related to the protection of personal rights in Indonesia is a state constitutional obligation regulated in the 1945 Constitution of the Republic of Indonesia Article 28G Paragraph (1). The constitutions of other countries such as in several Asian, African, and European countries as mentioned above have explicitly regulated and mentioned the protection of guarantees and personal rights or privacy rights of their citizens. while in Indonesia such as Saudi Arabia and Madagascar it does not explicitly mention anything about the right of privacy in their constitution. it can be concluded that the concept of personal data protection can be found in international and regional instruments such as the European Union Data Protection Directive, the European Union Data Protection Convention, and the OECD Guidelines.
\end{abstract}

KEYWORDS personal data protection, human rights, electronic transactions, constitution

\section{INTRODUCTION}

Negara berdasar atas hukum menempatkan hukum sebagai hal yang tertinggi (supreme) sehingga ada istilah supremasi hukum. Supremasi hukum harus tidak boleh mengabaikan 3 (tiga) ide dasar hukum yaitu keadilan, kemanfaatan, dan kepastian. Apabila negara berdasar atas hukum, pemerintahan negara itu juga harus berdasar atas suatu konstitusi atau Undang-Undang Dasar sebagai landasan penyelenggaraan pemerintahan.(Setiadi, 2012)

Konstitusi dalam negara hukum adalah konstitusi yang bercirikan gagasan konstitusionalisme yaitu adanya pembatasan atas kekuasaan dan jaminan hak dasar warga negara.(Darmadi, 2020) Umat manusia memilikinya bukan karena diberikan kepadanya oleh masyarakat atau berdasarkan hukum positif, melainkan semata-mata berdasarkan martabatnya sebagai manusia. Dalam arti ini, maka meskipun setiap orang terlahir dengan warna kulit, jenis kelamin, bahasa, budaya dan kewarganegaraan yang berbeda-beda, tetapi tetap mempunyai hak-hak tersebut. Inilah sifat universal dari hak-hak tersebut. Selain 
bersifat universal, hak-hak itu juga tidak dapat dicabut (inalienable).(Smith \& Marzuki, 2008)

Asas perlindungan dalam negara hukum tampak antara lain dalam Declaration of Independent. Deklarasi tersebut mengandung asas bahwa orang yang hidup di dunia ini, sebenarnya telah diciptakan merdeka oleh Tuhan, dengan dikaruniai beberapa hak yang tidak dapat dirampas atau dimusnahkan, hak tersebut mendapat perlindungan secara tegas dalam negara hukum. Peradilan tidak semata-mata melindungi hak asasi perorangan, melainkan fungsinya adalah untuk mengayomi masyarakat sebagai totalitas agar supaya cita-cita luhur bangsa tercapai dan terpelihara. (Budhijanto, 2010)

Dalam Pasal 28G ayat (1) Undang-Undang Dasar Negara Republik Indonesia Tahun 1945 menyebutkan bahwa setiap orang berhak atas perlindungan diri pribadi, keluarga, kehormatan, martabat, dan harta benda yang di bawah kekuasaannya, serta berhak atas rasa aman dan perlindungan dari ancaman ketakutan untuk berbuat atau tidak berbuat sesuatu yang merupakan hak asasi manusia. Terkait hak pribadi sebagai hak asasi manusia dijelaskan Danrivanto Budhijanto, bahwa "Perlindungan terhadap hak-hak pribadi atau hak-hak privat akan meningkatkan nilai-nilai kemanusiaan, meningkatkan hubungan antara individu dan masyarakatnya, meningkatkan kemandirian atau otonomi untuk melakukan kontrol dan mendapatkan kepantasan, serta meningkatkan toleransi dan menjauhkan dari perlakuan diskriminasi serta membatasi kekuasaan pemerintah. (Budhijanto, 2010)

Jika melihat uraian di atas maka perlindungan diri pribadi sebagaimana disebutkan dalam Pasal 28G ayat (1) Undang-Undang Dasar Negara Republik Indonesia Tahun 1945 di atas erat kaitannya dengan perlindungan terhadap hak-hak pribadi atau hak-hak privat. Dalam sejarah perkembangannya, privasi merupakan suatu konsep yang bersifat universal dan dikenal di berbagai negara baik tertulis dalam bentuk undang-undang maupun tidak tertulis dalam bentuk aturan moral.(David, 2000) Hak tersebut berkaitan dengan kebutuhan spiritual manusia yaitu kebutuhan untuk dihargai perasaan, pikiran dan hak untuk menikmati kehidupannya atau disebut dengan the right to be let alone. (Warren \& Louis, 1890)

Perkembangan sistem komputer dan internet membuat informasi menjadi mudah untuk dicari dan dibagi. Konsep dasar dari perlindungan data pribadi pertama muncul sekitar tahun 1960. Pada tahun 1970, Negara Bagian Hesse di Jerman adalah negara bagian pertama yang memberlakukan peraturan tentang perlindungan data, diikuti oleh hukum nasional di Swedia pada tahun 1973, Jerman Barat pada tahun 1977, Amerika Serikat pada tahun 1974, dan Prancis pada tahun 1978 dan Inggris pada tahun 1984.(Murray, 2013) Konsep perlindungan data sering diperlakukan sebagai bagian dari perlindungan privasi.

Perlindungan data pada dasarnya dapat berhubungan secara khusus dengan privasi seperti yang dikemukakan oleh Allan Westin yang untuk pertama kali mendefinisikan privasi sebagai hak individu, grup atau lembaga untuk menentukan apakah informasi tentang mereka akan dikomunikasikan atau tidak kepada pihak lain sehingga definisi yang dikemukakan oleh Westin disebut dengan information privacy karena menyangkut informasi pribadi. Perlindungan data juga merupakan hak asasi manusia yang fundamental, sejumlah negara telah mengakui perlindungan data sebagai hak konstitusional atau dalam bentuk 'habeas data' yakni hak seseorang untuk mendapatkan pengamanan terhadap 
datanya dan untuk pembenaran ketika ditemukan kesalahan terhadap datanya. Albania, Armenia, Filipina, Timor Leste, Kolombia dan Argentina adalah negara-negara dengan perbedaan sejarah dan budaya yang telah mengakui peran dari perlindungan data yang dapat memfasilitasi proses demokrasi dan telah menjamin perlindungannya dalam konstitusi mereka.(Greenleaf, 2012)

Pengumpulan dan penyebarluasan data pribadi merupakan pelanggaran terhadap privasi seseorang karena hak privasi mencakup hak menentukan memberikan atau tidak memberikan data pribadi. (Committee, 1988; Manthovani, 2015)Data pribadi merupakan suatu aset atau komoditas bernilai ekonomi tinggi.(Makarim, 2003) Isu mengenai pentingnya perlindungan data pribadi mulai menguat seiring dengan meningkatnya jumlah pengguna telepon seluler dan internet. Sejumlah kasus yang mencuat, terutama yang memiliki keterkaitan dengan kebocoran data pribadi seseorang dan bermuara kepada aksi penipuan atau tindak kriminal pornografi, menguatkan wacana pentingnya pembuatan aturan hukum untuk melindungi data pribadi.(Djafar \& Komarudin, 2014)

Nilai transaksi penjualan data pribadi konsumen pada tahun 2006 secara global telah mencapai 3 miliar dolar Amerika.(Peek, 2006) Pertumbuhan industri bank data tersebut demikian pesat sehingga telah melahirkan perusahaan-perusahaan bank data yang secara global telah menempatkan mereka menjadi perusahaan perusahaan yang memiliki pendapatan besar. Dengan demikian, informasi pribadi pelanggan telah menjadi aset yang sangat berharga bagi perusahaan-perusahaan tersebut di atas.(Zarsky, 2003)

Hal ini mencerminkan pengumpulan data pribadi yang tidak menghormati hak privasi seseorang. Kasus yang banyak terjadi di Indonesia adalah jual beli data konsumen. Konsumen yang datanya berhasil diperoleh menjadi target pemasaran suatu produk perusahaan atau perseorangan. Tidak sedikit pula pengguna internet menawarkan jasa jualbeli akun atau pengikut. Padahal praktik tersebut membuka ruang terjadinya penyalahgunaan data seseorang untuk melakukan kejahatan. Kasus terbaru yaitu penipuan dan penggelapan kartu kredit nasabah dengan tersangka Imam Zahali (IZ), yang menyebabkan kerugikan pihak bank sekitar Rp 250 juta setelah menggunakan kartu kredit nasabah untuk transaksi gesek tunai. Hasil kejahatan itu kemudian digunakan untuk kepentingan dirinya, salah satunya menunaikan ibadah haji di Tanah Suci Mekah. Pelaku mendapatkan data nasabah dengan cara membelinya di internet sebesar Rp 800 ribu untuk 25 data. Dari data tersebut, pelaku kemudian menghubungi korban dengan mengaku sebagai sales kartu kredit dan menawarkan untuk menaikkan limit kartu kredit.(Mei, 2016)

Bentuk lain dari diabaikannya perlindungan terhadap privasi adalah munculnya sebuah pesan berisi iklan yang biasa disebut Location-Based Messaging. Pesan tersebut akan terkirim otomatis kepada seseorang jika ia berada di tempat tertentu. Padahal, belum tentu ia pernah menyetujui suatu perjanjian dengan sang provider dan memperbolehkan mereka merekam setiap aktivitasnya.

Indonesia belum memiliki peraturan perundang-undangan yang secara khusus mengatur mengenai perlindungan data pribadi. Berbagai macam permasalahan di atas menuntut pemerintah Indonesia untuk melindungi masyarakat dan mengatur masalah perlindungan atas data pribadi dan menyiapkan berbagai bentuk perlindungan hukum. Selain itu, dalam Undang-Undang Nomor 17 Tahun 2007 tentang Rencana Pembangunan Jangka Panjang 2005-2025 juga telah ditentukan bahwa untuk mewujudkan bangsa yang 
berdaya saing harus meningkatkan pemanfaatan ilmu pengetahuan dan teknologi. Salah satunya melalui peraturan yang terkait dengan privasi. (Nasional, 2005)

Berdasarkan latar belakang masalah sebagaimana tersebut di atas, maka permasalahan yang penulis angkat adalah sebagai berikut: Bagaimana perbandingan hak atas perlindungan diri pribadi sebagai bagian dari HAM di Indonesia berdasarkan Pasal 28G UUD NRI 1945 dengan konstitusi di negara lain dan Bagaimana konsep dan perbandingan perlindungan data pribadi sebagai wujud dari hak asasi manusia perlindungan diri pribadi di Indonesia dan Negara lain.

\section{METHODOLOGY}

Jenis penelitian ini adalah penelitian yuridis normatif. Penelitian ini didahului dengan penelitian normative dengan cara study pustaka untuk memperoleh data sekunder. Jenis data dalam penelitian ini adalah data sekunder. Data sekunder adalah data yang diperoleh dari bahan pustaka. (Soekanto, 2006) Seluruh data yang telah terkumpul dianalisis secara yuridis kualitatif kemudian diuraikan dan disajikan secara terstruktur dan ilmiah agar dapat dilakukan analisis berupa penjabaran masalah yang terkait dengan penelitian ini secara analitis deskriptif.

Penelitian kepustakaan (library research) adalah cara pengumpulan data dengan mengadakan studi penelaahan terhadap buku-buku, literatur-literatur, catatan-catatan, dan laporan-laporan yang ada hubungannya dengan masalah yang dipecahkan. (Nazir, 2014) Penelitian kepustakaan dilakukan untuk mengumpulkan data sekunder. Data sekunder yang diperoleh dalam penelitian kepustakaan berupa bahan hukum yang terkait dengan penelitian, yakni berupa bahan hukum primer. sekunder serta tersier.

Bahan hukum primer merupakan bahan hukum yang bersifat mengikat artinya mempunyai otoritas yang terdiri dari perundang-undangan, catatan-catatan atau risalah dalam pembuatan perundang-undangan dan putusan-putusan hakim. Bahan hukum sekunder merupakan bahan hukum yang memberikan penjelasan,mengenai bahan hukum primer seperti makalah, tesis, jrunal dan artikel ilmiah. (Sumardjono, 2006) Bahan Hukum Tersier adalah bahan penunjang di luar bidang hukum yang oleh peneliti hukum dipergunakan untuk melengkapi ataupun menunjang data penelitiannya.(Soekanto, 2006) Bahan hukum tersier merupakan bahan hukum yang dapat melengkapi atau menunjang keterangan maupun data yang terdapat dalam hukum primer dan sekunder, diantaranya adalah, Kamus Hukum dan Kamus Besar Bahasa Indonesia (KBBI).

\section{RESULTS AND DISCUSSION}

1. Perbandingan Hak Atas Perlindungan Diri Pribadi Sebagai Bagian Dari HAM di Indonesia Berdasarkan Pasal 28G UUD NRI 1945 dengan Konstitusi di Negara Lain

\section{a. Perlindungan Diri Pribadi sebagai Bagian dari HAM}

Hak asasi (fundamental Untuk memahami hakikat Hak Asasi Manusia, terlebih dahulu akan dijelaskan pengertian dasar tentang hak. Secara definitive "hak" merupakan unsur normatif yang berfungsi sebagai pedoman berperilaku, melindungi kebebasan, kekebalan serta menjamin adanya peluang bagi manusia 
dalam menjaga harkat dan martabatnya. Hak sendiri mempunyai unsur-unsur sebagai berikut:(Azra, 2003)

1) Pemilik hak;

2) Ruang lingkup penerapan hak;

3) Pihak yang bersedia dalam penerapan hak

Ketiga unsur tersebut menyatu dalam pengertian dasar tentang hak. Dengan demikian hak merupakan unsur normatif yang melekat pada diri setiap manusia yang dalam penerapannya berada pada ruang lingkup hak persamaan dan hak kebebasan yang terkait dengan interaksinya antara individu atau dengan instansi.

Hak merupakan sesuatu yang harus diperoleh. Dalam kaitannya dengan pemerolehan hak ada dua teori yaitu teori McCloskey dan teori Joel Feinberg. Menurut teori McCloskey dinyatakan bahwa pemberian hak adalah untuk dilakukan, dimiliki, atau sudah dilakukan. Sedangkan dalam teori Joel Feinberg dinyatakan bahwa pemberian hak penuh merupakan kesatuan dari klaim yang absah (keuntungan yang didapat dari pelaksanaan hak yang disertai pelaksanaan kewajiban). Dengan demikian keuntungan dapat diperoleh dari pelaksanaan hak bila disertai dengan pelaksnaan kewajiban. Hal itu berarti anatara hak dan kewajiban merupakan dua hal yang tidak dapat dipisahkan dalam perwujudannya. Karena itu ketika seseorang menuntut hak juga harus melakukan kewajiban.(Azra, 2003)

John Locke menyatakan bahwa hak asasi manusia adalah hak-hak yang diberikan langsung oleh Tuhan Yang Maha Pencipta sebagai hak yang kodrati. Oleh karenanya, tidak ada kekuasaan apapun di dunia yang dapat mencabutnya. Hak ini sifatnya sangat mendasar (fundamental) bagi hidup dan kehidupan manusia dan merupakan hak kodrati yang tidak bisa terlepas dari dan dalam kehidupan manusia.(Effendi, 1994)

Dalam Undang-Undang Nomor 39 Tahun 1999 tentang Hak Asasi Manusia Pasal 1 disebutkan bahwa "Hak Asasi Manusia (HAM) adalah seperangkat hak yang melekat pada hakikat dan keberadaan manusia sebagai makhluk Tuhan Yang Maha Esa dan merupakan anugerah-Nya yang wajib dihormati, dijunjung tinggi, dan dilindungi oleh negara, hukum, pemerintah dan setiap orang demi kehormatan serta perlindungan harkat dan martabat manusia."

Berdasarkan beberapa rumusan pengertian HAM tersebut, diperoleh suatu kesimpulan bahwa HAM merupakan hak yang melekat pada diri manusia yang bersifat kodrati dan fundamental sebagai suatu anugerah Tuhan yang harus dihormati, dijaga dan dilindungi oleh setiap individu, masyarakat atau negara. Dengan demikian hakikat penghormatan dan perlindungan terhadap HAM ialah menjaga keselamatan eksistensi manusia secara utuh melalui aksi keseimbangan yaitu keseimbangan antara hak dan kewajiban, serta keseimbangan antara kepentingan perseorangan dan kepentingan umum.

Upaya menghormati, melindungi, dan menjunjung tinggi HAM, menjadi kewajiban dan tanggung jawab bersama antara individu, pemerintah, bahkan negara. Jadi dalam memenuhi dan menuntut hak tidak terlepas dari pemenuhan kewajiban 
yang harus dilaksanakan. Begitu juga dalam memenuhi kepentingan perseorangan tidak boleh merusak kepentingan orang banyak (kepentingan umum). Karena itu pemenuhan, perlindungan dan penghormatan terhadap HAM harus diikuti dengan kewajiban asas manusia dan tanggung jawab asasi manusia dalam kehidupan pribadi, bermasyarakat, dan bernegara.

Konsep hak asasi manusia menurut Leach Levin (aktivis HAM) memiliki dua pengertian dasar. Pertama, bahwa hak-hak yang tidak dapat dipisahkan atau dicabut adalah hak asasi manusia. Hak-hak ini adalah hak-hak moral yang berasal dari kemanusiaan setiap insan. Tujuan dari hak tersebut adalah untuk menjamin martabat setiap manusia. Kedua, adalah hak-hak menurut hukum yang dibuat sesuai dengan proses pembentukan hokum yang dibuat sesuai dengan proses pembentukan hukum dari masyarakat itu sendiri, baik secara nasional maupun internasional.(Tholhah Hasan, 2001)

Dalam kaitannya dengan Hak Asasi Manusia, hak pribadi sebagaimana disimpulkan oleh Edmon Makarim dari beberapa pendapat ahli, yakni:(Makarim, 2010)

a) hak untuk tidak diusik oleh orang lain kehidupan pribadinya;

b) hak untuk merahasiakan informasi-informasi yang bersifat sensitif yang menyangkut dirinya; dan

c) hak untuk mengontrol penggunaan data pribadinya oleh pihak-pihak lain

Terkait perlindungan hak-hak pribadi diatur dalam Undang-Undang Dasar Negara Republik Indonesia Tahun 1945 Pasal 28G ayat (1), yang menyatakan bahwa "Setiap orang berhak atas perlindungan diri pribadi, keluarga, kehormatan, martabat, dan harta benda yang di bawah kekuasaannya, serta berhak atas rasa aman dan perlindungan dari ancaman ketakutan untuk berbuat atau tidak berbuat sesuatu yang merupakan hak asasi."

Dalam Pasal 17 Undang-Undang Nomor 12 Tahun 2005 tentang Pengesahan International Covenant on Civil and Political Rights (Konvenan Internasional tentang Hak-hak Sipil dan Politik), diatur bahwa:(Nasution, 1997)

(1) Tidak boleh seorang pun yang dengan sewenang-wenang atau secara tidak sah dicampuri masalah pribadi, keluarga, rumah atau korespondensinya, atau secara tidak sah diserang kehormatan dan nama baiknya.

(2) Setiap orang berhak atas perlindungan hukum terhadap campur tangan atau serangan tersebut.

ASEAN Human Rights Declaration yang baru saja diadopsi negara-negara ASEAN juga secara jelas mengakui hak privasi atas data pribadi dalam Pasal 21. Dewasa ini, telah banyak negara yang undang-undangnya mengatur tentang perlindungan data, setidaknya terdapat lebih dari 120 negara yang memiliki hukum tentang perlindungan data. (Greenleaf, 2012) 


\section{b. Perbandingan Hak Perlindungan Diri Pribadi Di Indonesia (Pasal 28G UUD 1945) Dengan Hak Perlindungan Diri Pribadi Di Konstitusi Negara Lain}

Amanden UUD 1945 telah memasukkan jaminan perlindungan dan pemenuhan hak warga negara dalam konstitusi. Beberapa Pasal di dalam UUD NRI Tahun 1945 mengatur secara komprehensif tentang hak-hak asasi warga negara dan sekaligus kewajiban. Pasal-pasal hak asasi manusia (HAM) sebagai wujud jaminan atas perlindungannya dituangkan dalam bab tersendiri, yaitu pada Bab X dengan judul "Hak Asasi Manusia", yang di dalamnya terdapat 10 (sepuluh) pasal tentang HAM ditambah 1 pasal (Pasal 28) dari bab sebelumnya (Bab X) tentang "Warga Negara dan Penduduk", sehingga ada 11 (sebelas ) pasal tentang HAM, mulai dari Pasal 28, 28A sampai dengan Pasal 28J. Terkait perlindungan hak-hak pribadi diatur dalam Undang-Undang Dasar Negara Republik Indonesia Tahun 1945 Pasal 28G ayat (1), yang menyatakan bahwa :

"Setiap orang berhak atas perlindungan diri pribadi, keluarga, kehormatan, martabat, dan harta benda yang di bawah kekuasaannya, serta berhak atas rasa aman dan perlindungan dari ancaman ketakutan untuk berbuat atau tidak berbuat sesuatu yang merupakan hak asasi."

Dari konstitusi negara-negara Asia negara yakni, Timor Leste, Vietnam, Myanmar, Thailand, Korea Selatan, Mongolia, Phillipina telah dengan tegas mengatur dan menyebutkan perlindungan atas jaminan dan hak-hak pribadi atau hak-hak privat (privasi) atas warga negaranya. Sementara 1 (satu) Negara yakni Arab Saudi tidak dengan tegas menyebutkan mengenai privasi namun hanya menyebutkan tindakan memasuki rumah tanpa seizin pemiliknya (trespassing) dan juga penyadapan terhadap segala bentuk korespondensi baik melalui telegraf, pos, dan bentuk komunikasi lainnya adalah dilarang kecuali ditetapkan oleh hukum.

Jika dibandingkan dengan Pasal 28G UUD 1945 yang menyebutkan bahwa setiap orang berhak atas perlindungan diri pribadi, keluarga, kehormatan, martabat, dan harta benda yang di bawah kekuasaannya, serta berhak atas rasa aman dan perlindungan dari ancaman ketakutan untuk berbuat atau tidak berbuat sesuatu yang merupakan hak asasi manusia, memang tidak menyebutkan dengan tegas mengenai privasi. Namun perlindungan diri pribadi juga terwujud dalam perlindungan terhadap hak-hak privat. Perlindungan terhadap hak-hak privat termasuk di dalamnya perlindungan terhadap data pribadi, menurut Allan Westin individu menentukan apakah informasi tentang mereka akan dikomunikasikan atau tidak kepada pihak lain sehingga definisi yang dikemukakan oleh Westin disebut dengan information privacy karena menyangkut informasi pribadi.

\section{Konsep dan Perbandingan Perlindungan Data Pribadi Sebagai Wujud Dari Hak Perlindungan Diri Pribadi di Indonesia dan Negara Lain}

\section{a. Konsep Perlindungan Data Pribadi sebagai Hak Privasi}

Suatu data adalah data pribadi apabila data tersebut berhubungan dengan seseorang, sehingga dapat digunakan untuk mengidentifikasi orang tersebut, yaitu pemilik data. (fondamentaux et al., 2014) Penjelasan mengenai definisi data 
pribadi adalah hal penting untuk menjamin perlindungan data tersebut. Sejauh ini dalam beberapa instrumen internasional dan regional seperti dalam European Union Data Protection Directive, European Union Data Protection Convention, dan the OECD Guidelines yang dimaksud dengan "data pribadi" adalah semua data yang berhubungan dengan orang-perorangan yang teridentifikasi dan dapat diidentifikasi (information relating to an identified or identifiable natural person). Yang masih menjadi perdebatan semenjak peraturan-peraturan tersebut diberlakukan adalah jenis data yang dapat dikategorikan sebagai data pribadi. Otoritas perlindungan data yang diatur dalam Convention for the Protection of Individuals with Regard to Automatic Processing of Personal Data telah memberikan interpretasi yang berbeda namun pada intinya data itu berhubungan dengan individu walaupun informasi yang teridentifikasi telah terpisah akan tetapi mendapatkan perlindungan mengingat data tersebut tidak dianggap sebagai data yang tidak bernama. (de l’Europe, 1981)

Hak perlindungan data pribadi berkembang dari hak untuk menghormati kehidupan pribadi atau disebut the right to private life. Konsep kehidupan pribadi berhubungan dengan manusia sebagai makhluk hidup. Dengan demikian orang perorangan adalah pemilik utama dari hak perlindungan data pribadi.(Greer et al., 2018)

Dalam konteks Indonesia, Dalam Putusan No.5/PUU-VIII/2011, MK juga menulis bahwa right to privacy merupakan bagian dari hak asasi manusia (derogable rights) dan cakupan dari right to privacy meliputi informasi atau right to information privacy, disebut juga data privacy (data protection). Sejumlah peraturan dan putusan pengadilan juga meneguhkan hak privasi.

Peraturan delegasi dari UU ITE, PP No. 82 Tahun 2012 tentang Penyelenggara Sistem dan Transaksi Elektronik, memuat definisi data pribadi yaitu data perseorangan tertentu yang disimpan, dirawat, dijaga kebenaran serta dilindungi kerahasiaannya (Pasal 1 angka 27). (Supriyadi, 2018)

\section{b. Perbandingan Penerapan Hak Perlindungan Data Pribadi di di Negara lain dan di Indonesia}

\section{1) General Data Protection Regulation (GDPR)}

European Union (Uni Eropa) mengatur mengenai perlindungan data pribadi atau privasi dan ada yang diatur selanjutnya oleh peraturan selanjutnya. Seperti Uni Eropa dalam rangka perlindungan hak privasi telah sepakat mengeluarkan Peraturan Perlindungan Data atau General Data Potection Regulation (GDPR). Peraturan ini disahkan pada tahun 2006 oleh Uni Eropa yang kemudian berlaku dimulai pada tanggal 25 Mei 2018 diseluruh negara anggota Uni Eropa yang berjumlah 28 Negara. (Avenue et al., 2018)

EU GDPR merupakan serangkaian peraturan baru yang bertujuan memperkuat pelindungan data pribadi serta memastikan konsistensi penerapan pelindungan tersebut di seluruh Uni Eropa. Peraturan ini dikembangkan dari Petunjuk Pelindungan Data Uni Eropa 1995 yang telah ada sebelumnya, seperangkap peraturan penting yang disusun sebelum 
hadirnya ponsel pintar dan media sosial serta layanan daring lainnya (mesin pencarian, surel, dll.) yang ditawarkan oleh pemerintah secara gratis kepada pengguna, tetapi didanai dengan periklanan bertarget berbasis data. Peraturan Uni Eropa memperluas pelindungan privasi dari petunjuk sebelumnya dan menerapkan langkah-langkah pelindungan baru untuk merespon perkembangan teknologi yang muncul. GDPR akan menggantikan aturan perlindungan data yang ada di bawah Directive 95/46/ EC dari Parlemen Eropa dan Council (EU Directive).(Directive, 1995)

Di tengah perkembangan teknologi dan globalisasi, konstitusionalisasi hak mendasar untuk perlindungan data di Uni Eropa dan fragmentasi kerangka legislatif yang dihasilkan dari EU Directive, GDPR memiliki tujuan dan perubahan utama berikut:

a) menyelaraskan dan menyederhanakan kerangka kerja untuk pasar tunggal digital;

b) menempatkan individu mengendalikan data mereka; dan

c) merumuskan tata kelola perlindungan data modern.

Terdapat kategori khusus mengenai data pribadi yaitu seperti data pribadi yang mengungkapkan asal ras atau etnis, opini politik, agama atau keyakinan filosofis, keanggotaan serikat pekerja, data mengenai kesehatan atau data mengenai kehidupan seks seseorang atau orientasi seksual seseorang, dan data genetik atau data biometrik yang diproses untuk tujuan unik mengidentifikasi orang alami.(Voss, 2016)

\section{2) Personal Data Protection Act Malaysia (PDPA)}

Data Pribadi di Malaysia dilindungi oleh the Personal Data Protection Act No. 709 of 2010 (PDPA Malaysia). Seksi 5 sampai dengan Seksi 12 PDPA. Malaysia memuat tujuh prinsip perlindungan data pribadi yaitu: prinsip umum pengolahan berdasarkan persetujuan, pemberitahuan dan pilihan, pengungkapan, keamanan, integritas data (retensi dan akses)

Prinsip-prinsip tersebut lebih dipengaruhi oleh EU Data Protection Directive daripada OECD Guidelines atau APEC Framework.

Isi dari UU ini mengatur keseluruhan mengenai data ribadi. Dalam Part 2 tentang Personal Data Protection Division 1 Section 5 mengatur tentang pengelolaan data pribadi oleh pengguna data harus sesuai dengan Prinsip Perlindungan Data Pribadi. Prinsip tersebut yaitu:(Leong \& Bakar, 2010)

a) Prinsip umum

b) Prinsip pemberitahuan dan pilihan

c) Prinsip pengungkapan

d) Prinsip keamanan

e) Prinsip retensi

f) Prinsip integritas data

g) Prinsip akses.

Artinya ketentuan tersebut apabila ingin mengelola data pribadi di Malaysia harus memperhatikan prinsip perlindungan data pribadi. Namun 
yang dapat mengelola data pribadi disebutkan yaitu setiap orang yang memproses dan setiap orang yang memilii kendali atau orientasi pengelolaan data pribadi apa pun sehubungan dengan transaksi komersial.

Terdapat beberapa larangan bagi pengguna data pribadi yaitu: pengguna data tidak boleh

(1) Dalam hal data pribadi selain data pribadi yang sensitif data, mengelolah data pribadi tentang subjek data kecuali subjek data telah memberikan persetujuannya pada pemprosesan data ribadi.

(2) Dalam hal data pribadi yang sensitif, proses yang sensitif data pribadi tentang subjek data kecuali sesuai dengan ketentuan pasal 40 .

\section{3) Personal Data Privacy Ordinance of 1995 (PDPO) Hong Kong}

PDPO merupakan peraturan perundang-undangan yang pertama kali mengatur masalah privasi data secara komprehensif, di Asia. Selama 18 (delapan belas) tahun diimplementasikan oleh Privacy Commisioner for Personal Data (PCPD) yaitu otoritas di Hongkong yang menangani masalah privasi data. Prinsip perlindungan privasi data yang terkandung dalam PDPO tidak dapat sepenuhnya dilaksanakan. Oleh karena itu, dilakukan perubahan besar terhadap PDPO pada tahun 2012. (Greenleaf, 2014) Prinsip Perlindungan Data Pribadi di Hongkong terdapat 6, yaitu:

a) Batasan Pengumpulan Data Pribadi

Pengumpulan data pribadi terbatas pada pengumpulan data pribadi secara sah untuk tujuan yang secara langsung berhubungan dengan fungsi dari pengumpul. Data yang dikumpulkan harus cukup, namun pengumpulan data pribadi tidak boleh melebihi tujuan pengumpulan data tersebut di atas.(Alhadeff et al., 2012)

b) Penggunaan dan Pengungkapan Data Pribadi

Prinsip ini membatasi pengungkapan data pribadi hanya untuk atau secara langsung berhubungan dengan tujuan awal pengumpulan data pribadi tersebut, atau apabila subjek data menyatakan persetujuan.

c) Kewajiban Kualitas Data dan Pemberian Saran kepada Pihak Ketiga Prinsip ini mewajibkan seluruh langkah yang mungkin diambil untuk menjamin akurasi data pribadi (dengan mempertimbangkan tujuan penggunaan dan setiap tujuan yang langsung berhubungan), dan untuk menghapus atau tidak menggunakan data yang tidak akurat. Data yang tidak akurat didefinisikan sebagai data yang tidak benar, menyesatkan, tidak lengkap, atau tidak mutakhir. (Yu, 2005) Penggunaan data yang tidak akurat tidak dengan sendirinya menjadi suatu pelanggaran apabila seluruh langkah yang mungkin untuk menghindari tidak akuratnya data tersebut telah diambil.

Komisioner dapat mengeluarkan "enforcement notice" (surat teguran), yang meminta perbaikan-perbaikan secara sistematis apabila langkahlangkah penjaminan akurasi data tidak dilakukan. Subjek data dapat meminta untuk mengoreksi informasi yang tidak akurat. (Mo, 2017) Ketika pihak ketiga menerima data yang tidak akurat, "data user" harus, 
apabila memungkinkan menginformasikan pihak ketiga tersebut agar subjek data dapat memperbaiki data

d) Penghapusan dan Pemusnahan Data Pribadi

Berdasarkan prinsip ini, data pribadi tidak boleh disimpan lebih lama dari jangka waktu yang diperlukan untuk pemenuhan tujuan (termasuk setiap tujuan yang langsung berhubungan) untuk tujuan tersebut data digunakan atau akan digunakan di masa depan.

e) Kewajiban Keamanan Data

Berdasarkan prinsip ini, pengelola data pribadi wajib melakukan setiap langkah yang memungkinkan untuk melindungi data pribadi dari akses yang tidak disengaja, atau pemrosesan, penghapusan, penghilangan, dan penggunaan tidak sah (tanpa hak). Tindakan-tindakan pengamanan data ini memperhatikan berbagai faktor, misalnya jenis data, lokasi penyimpanan fisik data, dan potensi-potensi bahaya terhadap data. PDPO tidak memberikan pengaturan khusus terhadap data sensitif, tidak seperti hukum di Eropa.

f) Keterbukaan mengenai praktik-praktik

"Data User" harus mengambil langkah-langkah untuk menjamin bahwa setiap orang (tidak hanya subjek data) dapat menentukan kebijakan dan praktik mengenai data pribadi, jenis data pribadi yang disimpan "Data User", dan tujuan utama penggunaannya. Prinsip ini diambil dari OECD "openess" principle. Prinsip ini digunakan oleh Komisioner untuk mewajibkan organisasiorganisasi dan badan hukum di Hong Kong memublikasikan Kebijakan Privasi (Privacy Policy Statement) mereka ke publik. Ketiadaan Publikasi kebijakan privasi di perusahaanperusahaan ataupun organisasi merupakan pelanggaran dari prinsip ini dan Komisioner di Hong Kong dapat melayangkan surat teguran (enforcement notice).

\section{CONCLUSION}

1. Terkait perlindungan hak-hak pribadi di Indonesia merupakan kewajiban konstitusi negara yang diatur dalam diatur dalam Undang-Undang Dasar Negara Republik Indonesia Tahun 1945 Pasal 28G ayat (1), yang menyatakan bahwa "Setiap orang berhak atas perlindungan diri pribadi, keluarga, kehormatan, martabat, dan harta benda yang di bawah kekuasaannya, serta berhak atas rasa aman dan perlindungan dari ancaman ketakutan untuk berbuat atau tidak berbuat sesuatu yang merupakan hak asasi." Dari konstitusi negara-negara lain seperti di beberapa negara Asia, Afrika, dan Eropa sebagaimana tersebut di atas sebagian telah dengan tegas mengatur dan menyebutkan perlindungan atas jaminan dan hak-hak pribadi atau hak-hak privat (privasi) atas warga negaranya. Sementara seperti di negara Indonesia yakni Arab Saudi dan Madagaskar tidak dengan tegas menyebutkan apa-apa saja yang mengenai hak privasi didalam konstitusi mereka.

2. Konsep terhadap perlindungan data pribadi dapat kita temukan dalam instrumen internasional dan regional seperti dalam European Union Data Protection Directive, 
European Union Data Protection Convention, dan the OECD Guidelines. Dimana Hak perlindungan data pribadi berkembang dari hak untuk menghormati kehidupan pribadi atau disebut the right to private life.

\section{REFERENCES}

Budhijanto, D. (2010). Hukum telekomunikasi, penyiaran, dan teknologi informasi: Regulasi dan konvergensi. Refika Aditama.

Committee, U. H. R. (1988). CCPR general comment No. 16: Article 17 (right to privacy), the right to respect of privacy, family, home and correspondence, and protection of honour and reputation. April.

Darmadi, N. S. (2020). Kedudukan dan Wewenang Mahkamah Konstitusi dalam Sistem Hukum Ketatanegaraan Indonesia. Jurnal Hukum, 26(2), 667-690.

David, B. (2000). Privacy \& Human Rights 2000: An international survey of privacy laws and developments. Electronic Privacy Information Center, Washington, DC, USA and Privacy International, London, UK Http://Www. Privacyinternational. Org/Survey/Index. Html.

Djafar, W., \& Komarudin, A. (2014). Perlindungan Hak Atas Privasi Di Internet-Beberapa Penjelasan Kunci. Elsam, Jakarta.

Greenleaf, G. (2012). Global data privacy laws: 89 countries, and accelerating. Privacy Laws \& Business International Report, 115.

Makarim, E. (2003). Kompilasi hukum telematika. Divisi Buku Perguruan Tinggi, RajaGrafindo Persada.

Manthovani, D. R. (2015). Penyadapan Vs. Privasi. Bhuana Ilmu Populer.

Mei, A. (2016). Duh! Sales Kartu Kredit Gadungan ini Gunakan Uang Haram Buat Naik Haji. https://news.detik.com/berita/d-3158671/duh-sales-kartu-kredit-gadungan-inigunakan-uang-haram-buat-naik-haji

Murray, A. (2013). Information technology law: The law and society. Oxford University Press. Nasional, K. M. N. P. P. (2005). Rancangan Awal Rencana Pembangunan Jangka Panjang Nasional Tahun 2005-2025. Jakarta. Badan Perencanaan Pembangunan Nasional.

Nazir, M. (2014). Metode Penelitian Cet. 9. Penerbit Ghalia Indonesia. Bogor.

Peek, M. E. (2006). Information Privacy and Corporate Power: Toward a Re-Imagination of Information Privacy Law. Seton Hall L. Rev., 37, 127.

Setiadi, W. (2012). Pembangunan Hukum dalam Rangka Peningkatan Supremasi Hukum. Jurnal Rechts Vinding: Media Pembinaan Hukum Nasional, 1(1), 1-15.

Smith, R. K., \& Marzuki, S. (2008). Hukum hak asasi manusia. Pusat Studi Hak Asasi Manusia, Universitas Islam Indonesia (PUSHAM UII).

Soekanto, S. (2006). Pengantar penelitian hukum. Penerbit Universitas Indonesia (UI-Press). 
Sumardjono, M. S. (2006). Bahan Kuliah Metodologi Penelitian Ilmu Hukum. UGM, Yogyakarta.

Warren, S. D., \& Louis, D. (1890). Brandeis, The Right to Privacy, 4 Harv. L. Rev, 193(10.2307), 1321160.

Zarsky, T. Z. (2003). Thinking outside the box: Considering transparency, anonymity, and pseudonymity as overall solutions to the problems in information privacy in the internet society. U. Miami L. Rev., 58, 991. 